\title{
The submarine hydrothermal system of Panarea (Southern Italy): biogeochemical processes at the thermal fluids-sea bottom interface
}

\author{
Concetta Gugliandolo $\left({ }^{1}\right)$, Francesco Italiano $\left({ }^{2}\right)$ and Teresa L. Maugeri $\left({ }^{1}\right)$ \\ (') Dipartimento di Biologia Animale ed Ecologia Marina, Università degli Studi di Messina, Italy \\ ${ }^{(2)}$ Istituto Nazionale di Geofisica e Vulcanologia, Sezione di Palermo, Italy
}

\begin{abstract}
Among the submarine hydrothermal systems located off-shore the volcanic archipelago of the Eolian Islands (Southern Italy), the most active is located off the coasts of Panarea Island. Thermal waters, gases and sulphur deposits coexist at the sea bottom where hydrothermal fluids are released from both shallow and deep vents. The chemical and isotopic composition of the fluid phase shows the presence of a significant magmatic component and the physico-chemical conditions of the geothermal reservoir allow the release of reduced chemical species that are microbially mediated towards the production of organic carbon as a form of biochemical energy. Microorganisms inhabiting this environment possess nutritional requirements and overall metabolic pathways ideally suited to such ecosystem that represents a clear example of the close connection between geosphere and biosphere. Microscopic examination of the white mat attached to rock surfaces showed the presence of Thiothrix-like filamentous bacteria. Moderately thermophilic heterotrophic isolates were identified as strains of the genus Bacillus. Although the hydrothermal system of Panarea has to be considered a «shallow» system, it shows many characteristics that make it similar to the «deep» oceanic systems, giving a unique opportunity for improving our knowledge on such an unexplored world by working at this easily accessible site.
\end{abstract}

Key words submarine hydrothermal activity - fluids geochemistry - sulphur deposits - microbial communities

\section{Introduction}

The volcanic arc of the Eolian archipelago consists of seven volcanic islands and some sea-mounts formed and developed during the Quaternary. Two islands are still active volca-

Mailing address: Prof. Teresa L. Maugeri, Dipartimento di Biologia Animale ed Ecologia Marina, Università degli Studi di Messina, Salita Sperone 31, 98166 Messina, Italy; e-mail: tmaugeri@unime.it noes: Stromboli that erupts with regular low energy blasts and Vulcano that is now in a state of solphataric activity. Low temperature vents are at Lipari and Panarea Islands; no in-land hydrothermal manifestations are recognisable on the other islands.

Recent investigations highlight the existence of both shallow and deep submarine hydrothermal exhalations off the coasts of all the islands (Italiano and Nuccio, 1991; Francofonte et al., 1996; Inguaggiato and Italiano, 1998). The researches developed off the eastern coasts of Panarea showed the presence of the most active submarine hydrothermal system at shallow depths of the Eolian arc.

The island of Panarea (fig. 1) consists of a volcanic structure that has evolved in recent ge- 


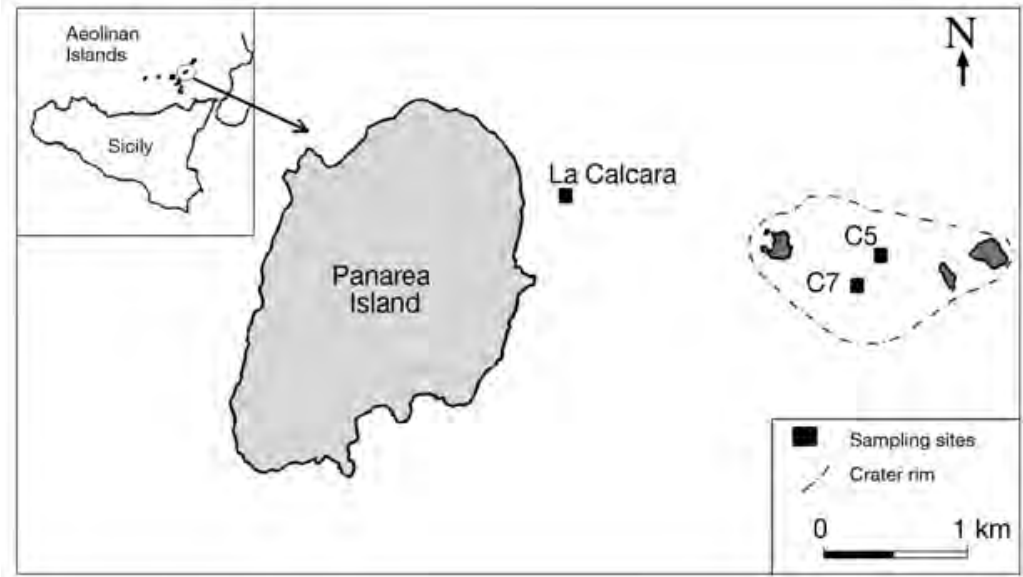

Fig. 1. Location of the hydrothermal area of Panarea Island and sampling sites.

ological times following different stages of activity: firstly, the central apparatus developed with the island of Panarea, then the volcanic structure enlarged to the East by a fault system NE-SW oriented. A group of islets, located to the East of the main island, are recognised as the remnants of a crater rim (Gabbianelli et al., 1986; Rossi et al., 1986). As reported by Italiano and Nuccio (1991), several gaseous emissions spread over the sea-bottom around Panarea area up to a depth of $150 \mathrm{~m}$. The area surrounded by the islets (about $4 \mathrm{~km}^{2}$ wide) was investigated up to a depth of $30 \mathrm{~m}$ by scuba-diving, and a great number of underwater exhalative vents were identified and clustered as submarine fields (Italiano and Nuccio, 1991). Their distribution is regulated by the NE-SW and NW-SE fault systems, which were recognised as having been active in recent times.

The released fluids consist of both gases and thermal waters whose temperatures, detected at the emission points, are in the range of $40 \div 95^{\circ} \mathrm{C}$. Generally the fluids come out from open fractures, but several areas with diffuse permeation of warm waters and gases through the sand on the seafloor were identified. A white mat surrounds all the areas where thermal waters discharge. The mat, sometimes, forms massive soft and white deposits (fig. 2) where rocky walls or any hard support is available.

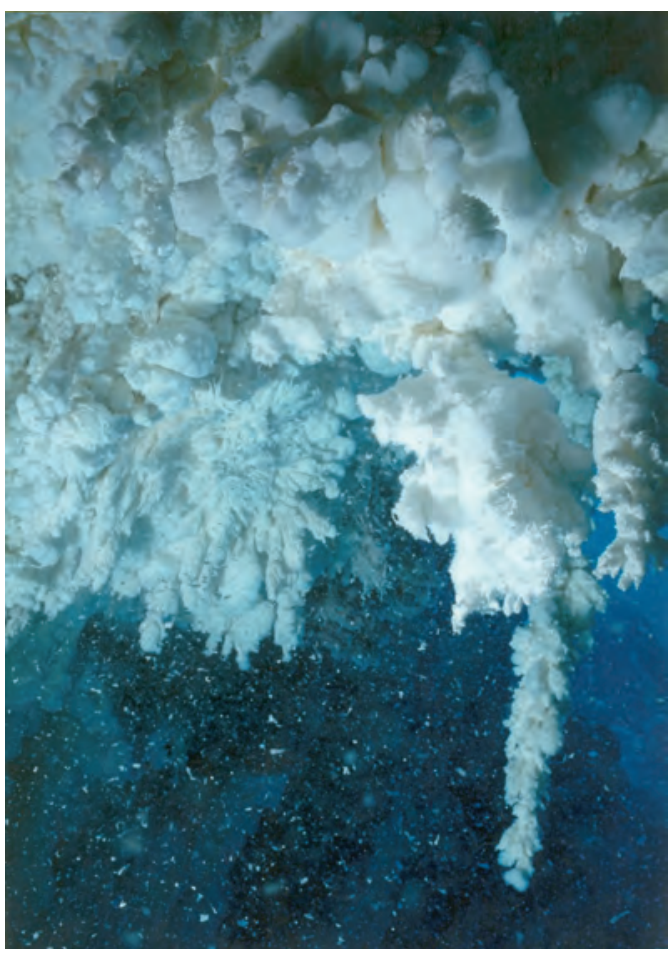

Fig. 2. Mat deposit at the C7 sampling site. The presence of a rocky wall as support allowed the large formation of thick, soft and white mat deposits mainly composed by bacteria. 
The input of energy due to the release of thermal fluids is considered to allow the production of biomass in the absence of light at deep-sea oceanic hydrothermal systems where the presence of chemosynthetic sulphur-oxidizing bacteria supports the hypothesis that chemosynthesis provides a substantial primary food source for the populations of invertebrates living close to the deep vents (Karl et al., 1980; Jannasch and Wirsen, 1981; Ruby et al., 1981; Tuttle et al., 1983; Jannasch, 1985). Microbial mats which cover the substratum on the seafloor near the vents opening represent a common feature of various submarine hydrothermal environments (Jannasch, 1985; Jacq et al., 1989; Taylor and Wirsen, 1997).

At shallow marine vent environments both photo- and chemosynthetic organisms occupy the lowest levels of the food chain. In addition to chemical compounds such as metabolic energy for chemosynthesizers, solar radiation represents the energy source for phototrophic planktonic organisms. The shallow marine hydrothermal vents of the Eolian Islands provide easily accessible sampling locations for studying microorganisms inhabiting extreme marine ecosystems. The thermal springs in the Baia di Levante of Vulcano (Eolian Islands) host dozens of aerobic and anaerobic, thermophilic, and hyperthermophilic microorganisms belonging to the Eubacteria and Archaea domain (Stetter et al., 1983; Fiala and Stetter, 1986; Huber et al., 1986; Huber and Stet- ter, 1989; Hafenbradl et al., 1996; Caccamo et al., 2000; Maugeri et al., 2001).

This paper focuses on the geosphere/biosphere relationships for which the submarine hydrothermal system of Panarea represents a clear example. Geochemical and microbiological considerations allowed to constrain the physicochemical characteristics of the deep-originated hydrothermal fluids feeding the vents where several microbial communities thrive.

\section{Sampling and analytical methods}

Water samples were collected at three stations (fig. 1) by Scuba divers. The thermal waters were collected by a syringe through a special stainless-steel probe which was inserted in the emission orifice in order to minimize the potential contamination by seawater (fig. 3). The sampling procedures for biological determinations followed those reported by Gugliandolo et al. (1999), while the samples collection for geochemical analyses followed the procedures described in Italiano and Nuccio (1991). Temperature was recorded in situ. Some preliminary analyses were performed on board of the research vessel, where chemical and biological laboratories were installed.

The bubbling gases were collected at the sea bottom by means of a stainless-steel funnel con-

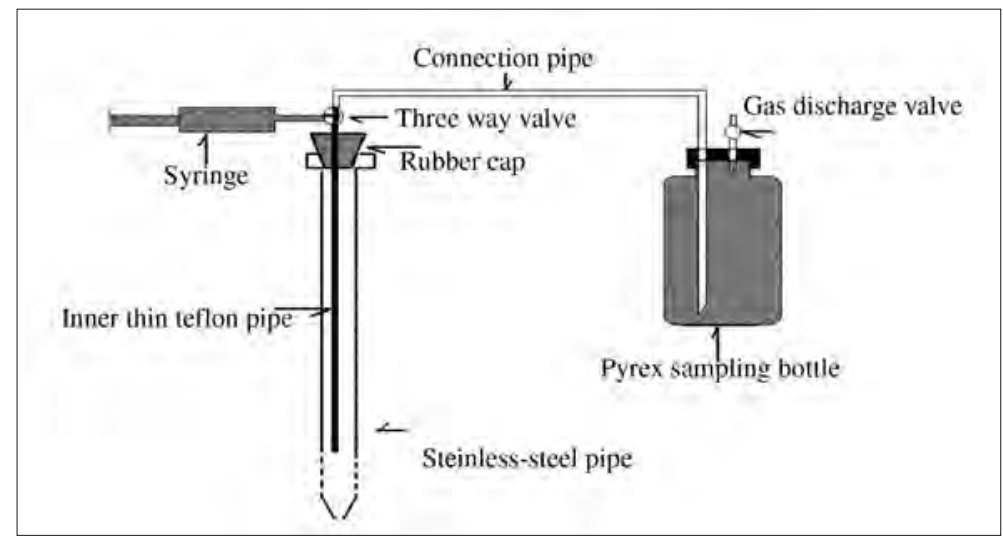

Fig. 3. Schematic representation of the sampling system (Gugliandolo et al., 1999). 
nected to two-way sampling bottles. The gas composition was determined by gas-chromatography (Perkin Elmer 8500) using argon as carrier gas and molecular sieve 5A column for gas separation. In order to evaluate the concentration of $\mathrm{H}_{2}, \mathrm{He}, \mathrm{O}_{2}, \mathrm{~N}_{2}, \mathrm{CO}_{2}$ a TCD detector was used while the $\mathrm{CH}_{4}$ and $\mathrm{CO}$ concentrations were determined by a FID detector associated with a methanizer. The detection limits (ppm by vol) were about 3 for $\mathrm{He}, 2$ for $\mathrm{H}_{2}$ and 0.5 for $\mathrm{CO}$ and $\mathrm{CH}_{4}$.

The $\mathrm{H}_{2} \mathrm{~S}$ content was determined on board the research vessel using reactive tubes (Drager) calibrated for both high and low sensitivities in the range $0.01-10 \mathrm{vol} \%$. The ${ }^{3} \mathrm{He} /{ }^{4} \mathrm{He}$ ratios were measured by a VG 5400 TFT mass spectrometer (resolving power of 600 at the $5 \%$ peak height; error $<1 \%$ ) and the ${ }^{4} \mathrm{He} /{ }^{20} \mathrm{Ne}$ ratio by a quadrupole mass spectrometer VG Mass-torr FX (accuracy $\pm 5 \%$ ). The $\mathrm{pH}$ and $\mathrm{HCO}_{3}{ }^{-}$values of water samples were determined immediately after sampling on board of the vessel. The cations and anions concentrations were determined in the laboratory by ion chromatography (Dionex 2000i) with a reproducibility within $\pm 2 \%$.

The microbial community was enumerated by direct counts of picoplankton (cells ranging from 0.2 to $2 \mu \mathrm{m}$ in diameter) following the method of Sieburth et al. (1978). Water samples were prefiltered through $2-\mu \mathrm{m}$ pore-size polycarbonate membrane filters, filtered onto $0.2-\mu \mathrm{m}$ polycarbonate (black) filters and fixed with formaldehyde (2\%). Picoplanktonic cells were stained with 4'6diamidino-2-phenylindole (DAPI) fluoro-chrome on $0.2-\mu \mathrm{m}$ membrane filters (Porter and Feig, 1980) using epifluorescence microscopy (Olympus BX-60M) at 1000x magnification. The microscope was equipped with an halogen (HG 100) light. G 330-385 exciter filter, FT 400 chromatic beam splitter and LP 420-barrier filter were used for picoplanktonic direct counts according to Maugeri et al. (1990).

To estimate the total number of autofluorescent cells, phototrophic picoplankton or picophytoplankton, filtered water samples were fixed with glutaraldehyde (1\%), and microscopically counted according to the procedure described by Maugeri et al. (1990). Blue light excitation, G470-490 exciter filter, FT 510 chromatic beam splitter, and LP 520-barrier filter were used.

Picoplanktonic cell counts were converted to biomass values, according to the method of Lee and Fuhrman (1987), by multiplying the biovolume values by the conversion factor proposed by Fry (1990). Biovolume was determined by measuring cells under the microscope and calculating the mean diameter of 100 cells observed for each field.

\section{Results and discussion}

\subsection{Hydrothermal fluids}

The analytical results of the sampled gases are reported in table I. Both the bubbling and dissolved gases show the typical characters of the geothermal fluids. All the sampled gases were $\mathrm{CO}_{2}$-dominated with $\mathrm{O}_{2} / \mathrm{N}_{2}$ ratios well below the atmosphere. $\mathrm{H}_{2} \mathrm{~S}$ was present with concentrations up to $2.5 \%$; other reactive gases $\left(\mathrm{H}_{2}\right.$, $\mathrm{CO}$ and $\mathrm{CH}_{4}$ ) were detected in concentrations up to 2000 ppm by vol; He was in the range of a few ppm by volume.

The deep physical characteristics of the hydrothermal reservoir off-shore the island of $\mathrm{Pa}-$ narea have been constrained by a geochemical

Table I. Chemical composition of the gases sampled during August-September 1996 and estimated equilibration temperature and pressure. The analytical results are expressed in vol\% for $\mathrm{CO}_{2}, \mathrm{H}_{2} \mathrm{~S}, \mathrm{~N}_{2}$ and $\mathrm{O}_{2}$; in ppm by vol for $\mathrm{He}, \mathrm{CO}, \mathrm{H}_{2}$ and $\mathrm{CH}_{4} . \mathrm{R} / \mathrm{Ra}=\mathrm{Helium}$ isotopic ratio normalized to the atmosphere $\left(\right.$ atmospheric ${ }^{3} \mathrm{He} /{ }^{4} \mathrm{He}=$ $\left.=1.39 \times 10^{-6}\right)$. na $=$ not analysed. The estimated equilibrium pressures are in bars.

\begin{tabular}{ccccccccccc}
\hline \hline Sample & $\mathrm{He}$ & $\mathrm{H}_{2}$ & $\mathrm{O}_{2}$ & $\mathrm{~N}_{2}$ & $\mathrm{CO}$ & $\mathrm{CH}_{4}$ & $\mathrm{CO}_{2}$ & $\mathrm{H}_{2} \mathrm{~S}$ & ${ }^{4} \mathrm{He} /{ }^{20} \mathrm{Ne}$ & $\mathrm{R} / \mathrm{Ra}$ \\
\hline La Calcara & 9 & 5 & 0.040 & 2.2 & 3.8 & 2158 & 97.5 & 0.3 & 12 & 4.01 \\
$\mathrm{C} 5$ & 12 & 15 & 0.045 & 1.1 & 3.4 & 1 & 96.5 & 2.3 & 26.7 & 4.1 \\
$\mathrm{C} 7$ & 9 & 5 & 0.005 & 0.4 & 0.5 & 160 & 93.0 & 1.8 & 37.5 & 4.3 \\
\hline
\end{tabular}


method based on the reactive gases $\left(\mathrm{CO}, \mathrm{CH}_{4}\right.$, $\mathrm{CO}_{2}$ and $\mathrm{H}_{2}$ ) of the submarine hydrothermal vents (Italiano and Nuccio, 1991). The deep temperatures of the thermal fluids are calculated to be in the range $190-315^{\circ} \mathrm{C}$ by the application of the gas-geothermobarometry considerations to the system $\mathrm{H}_{2} \mathrm{O}-\mathrm{CO}_{2}-\mathrm{CO}-\mathrm{CH}_{4}$, and assuming the existence of biphase boiling system at depth. The computed $P_{\mathrm{H}_{2} \mathrm{O}}$ values are relatively high, ranging between 13 and 105 bars. The calculated values of $\log P_{\mathrm{O}_{2}}$ range between $-32 \div-38$ showing a reducing environment (table II).

Table III lists the analytical results of the water samples. The chemical composition of $\mathrm{C} 5$ and $\mathrm{C} 7$ samples, shows a depletion in $\mathrm{Na}^{+}, \mathrm{Cl}^{-}$, $\mathrm{Mg}^{2+}$ and $\mathrm{SO}_{4}^{2-}$ compared to the seawater, while

Table II. Estimated equilibrium temperature and pressures for the sampled gases. Water pressure and oxygen fugacity expressed in bars.

\begin{tabular}{cccc}
\hline \hline Sample & $T^{\circ} \mathrm{C}$ & $P_{\mathrm{H}_{2} \mathrm{O}}$ & $\log f \mathrm{O}_{2}$ \\
\hline La Calcara & 236 & 30 & -37.7 \\
C5 & 314 & 105 & -30.1 \\
C7 & 192 & 13 & -41.4 \\
\hline
\end{tabular}

$\mathrm{K}^{+}$and $\mathrm{Ca}^{2+}$ are more concentrated. The sample taken at La Calcara site seems to be diluted by continental water or, alternatively, by steam condensation. Taking into considerations the calculated equilibrium temperatures, the recorded thermal water compositions agreed with high temperature water-rock interactions inside the deep geothermal body. Italiano and Nuccio (1991) considered these waters as the result of cold seawater mixed with waters of marine origin modified by high-temperature interaction with magmatic rocks (samples C5 and C7) or with low-salinity waters circulating beneath the main island (sample La Calcara).

The chemical characters of the submarine sampled thermal waters are similar to those reported for the hydrothermal solutions from the deep oceanic vents (Edmond et al., 1982; von Damm et al., 1985) showing that similar processes occur at these submarine sites whatever was their location at depth.

\subsection{Microbial abundances and biomasses}

Table IV shows the results obtained by direct counts of microbial abundances. Picoplankton

Table III. Chemical composition of the thermal water samples in comparison with local seawater (SW). The depth of the sampling site is reported in meters, conductivity in $\mathrm{mS} / \mathrm{cm}$ and concentrations in $\mathrm{mEq} / \mathrm{l}$. nd $=$ below the detection limits.

\begin{tabular}{cccccccccccccc}
\hline \hline Sample & Depth & $p H$ & $T^{\circ} \mathrm{C}$ & Cond & $\mathrm{HCO}_{3}^{-}$ & $\mathrm{Li}^{-}$ & $\mathrm{Na}^{+}$ & $\mathrm{K}^{+}$ & $\mathrm{Ca}^{2+}$ & $\mathrm{Mg}^{2+}$ & $\mathrm{Cl}^{-}$ & $\mathrm{Br}^{-}$ & $\mathrm{SO}_{4}^{2-}$ \\
\hline La Calcara & 19.8 & 5.1 & 95.0 & 36.2 & 3.0 & 1.2 & 341.6 & 9.3 & 19.6 & 82.2 & 415.5 & 0.7 & 38.6 \\
C5 & 18.4 & 4.7 & 48.0 & 41.1 & 1.5 & nd & 457.2 & 19.1 & 70.2 & 108.3 & 606.8 & 1.18 & 42.5 \\
C7 & 21.3 & 5.4 & 54.0 & 47.0 & 3.0 & 0.1 & 479.0 & 12.3 & 31.2 & 119.3 & 600.1 & 0.92 & 44.6 \\
SW & - & 8.1 & 15.0 & 54.0 & 2.5 & nd & 552.3 & 12.1 & 22.5 & 120.5 & 654.5 & 0.99 & 58.9 \\
\hline
\end{tabular}

Table IV. Picoplankton and Picophytoplankton abundances and calculated picoplanktonic biomasses in thermal waters sampled at the sea-bottom of Panarea. The local seawater (SW) is reported for comparison. $\mathrm{nd}=$ not determined.

\begin{tabular}{cccc}
\hline \hline Sample & $\begin{array}{c}\text { Picoplankton } \\
\left(10^{7} \text { cells/l) }\right.\end{array}$ & $\begin{array}{c}\text { Picophytoplankton } \\
\left(10^{6} \text { cells/l }\right)\end{array}$ & $\begin{array}{c}\text { Picoplanktonic } \\
\text { biomass }(\mu \mathrm{g} \mathrm{C} / 1)\end{array}$ \\
\hline La Calcara & 3.62 & 3.04 & 1.79 \\
C5 & 5.83 & 3.12 & 2.88 \\
C7 & 2.51 & 4.74 & 1.24 \\
SW & 100 & 30 & $\mathrm{nd}$ \\
\hline
\end{tabular}


and picophytoplankton (autofluorescent cells) ranged from $2.51 \times 10^{7}$ to $5.83 \times 10^{7}$ cells $/ 1$ and from $3.04 \times 10^{6}$ to $4.74 \times 10^{6}$ cells/ 1 respectively. Observations under blue light, showed that yellow-orange autofluorescent prokaryotic organisms, belonging to cyanobacteria, were more abundant than red autofluorescent ones, belonging to the Eukaryotic domain. Picoplanktonic biomasses were in the range of 1.24 and $2.88 \mu \mathrm{g}$ $\mathrm{C} / 1$ (table IV).

Heterotrophic thermophilic bacteria - Isolation of thermophilic aerobic bacteria from samples of La Calcara and their identification were carried out as described by Maugeri et al. (2001). Strains isolated from water and sediment samples were ascribed to the genus Bacillus. The phenotypic and genotypic characterization of the $7 \mathrm{~s}$ strain has been reported in Maugeri et al. (2001).

Microbial mat - From C7 vent site a sample of a white, filamentous mat was scraped from rocks adjacent to the hydrothermal vents and stored in a Corning plastic tube $(50 \mathrm{ml})$. On board, a subsample of this was fixed with formaldehyde (2\%) for subsequent microscopic investigation, and the rest was available for culturing experiments. Microscopic observation of a subsample from the whitish mat revealed a variety of morphologically distinct filamentous forms resembling to Thiothrix genus (fig. 4). The adopted culture techniques did not allowed their cultivation.

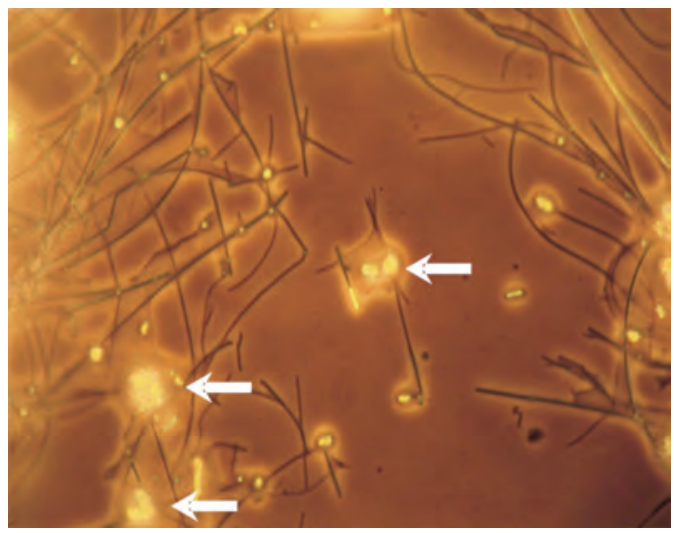

Fig. 4. Thiothrix-like filamentous bacteria (800x) from the whitish mat sampled at C7 site. It is possible to see the presence of sulphur connected to the bacteria.

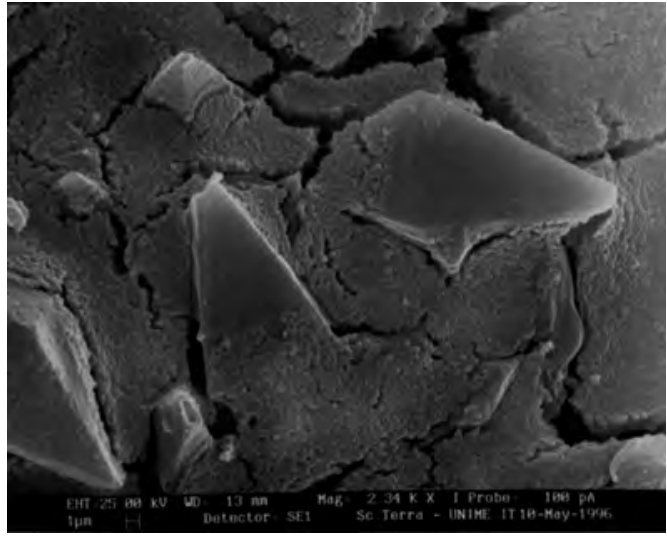

Fig. 5. Scanning electron microscope picture (2340x) of short rod bacteria and sulphur crystals grown from the $\mathrm{C} 7$ thermal water sample.

Sulphur-oxidizing bacteria - All strains obtained from water samples after enrichment and isolation on TB medium (Tuttle and Jannasch, 1972) were small, gram-negative, motile, rodshaped microorganisms. The isolates deposited sulphur externally onto agarised TB medium (fig. 5) and produced sulphate (low final $p H$ ) in liquid TB medium. None of the organisms was able to grow on these media at 55 or $60^{\circ} \mathrm{C}$, nor to grow on Marine Agar at any temperature investigated. Based on growth characteristics and cellular morphology, the isolates were ascribed to the genus Thiobacillus (Kelly and Harrison, 1989).

\subsection{Thermal fluids-sea bottom interface interactions}

Oxidation reactions are thought to be the major phenomenon occurring at the Benthic Boundary Layer (BBL) representing the geosphere/biosphere interface. It represents the interface between two natural systems: the oxidising (seawater) and the reducing (hydrothermal fluids) one. The oxygen content of the venting gases ranging from 50 to $500 \mathrm{ppm}(0.005-0.05 \mathrm{vol} \%)$ (table I) cannot come from the deep magmatic source as also shown by the negligible oxygen fugacity calculated for the fluids rising from the deep hydrothermal reservoir. Oxygen should 
originate from an atmospheric component that mixes with the deep-originated hydrothermal fluids at shallow levels. Since the investigated hydrothermal system is located in a submarine environment, we argue that air-saturated seawater is the carrier for the atmospheric-derived oxygen. The $\mathrm{N}_{2}$ concentration from 0.4 to $2.2 \mathrm{vol} \%$ (table I), implies that the oxygen was possibly consumed by redox reactions and also that $\mathrm{N}_{2}$ has also a different origin than from air. This agrees with the $\mathrm{N}_{2}$ excess always recorded in deep (volcanic and geothermal) gases.

The $\mathrm{H}_{2}$ content in the sampled gases is seldom very low and not consistent with the values normally found in gas manifestations linked with geothermal fields. The possibility that $\mathrm{H}_{2}$ is lost because of oxidation processes due to the presence of atmospheric contribution to the hydrothermal fluids was taken into consideration, but the undetectable oxygen concentrations and the high ${ }^{4} \mathrm{He} /{ }^{20} \mathrm{Ne}$ ratios (about 100 times higher than the atmosphere: $R_{a t m}=0.318$ ) ruled out this possibility.

Alternatively this lost can be due to chemical reactions affecting the $\mathrm{H}_{2}$ content during a slow rising of the fluid from the reservoir to the seafloor which allows a partial equilibration in a chemical reaction involving $\mathrm{H}_{2} \mathrm{~S}$ and $\mathrm{SO}_{2}$ species. The reaction (3.1) involves most of the gaseous species of the submarine vents, and it allows expressing the $P_{\mathrm{H}_{2}}$ as reported in the eq. (3.2)

$$
\begin{aligned}
& \mathrm{H}_{2} \mathrm{~S}_{(g)}+4 \mathrm{H}_{2} \mathrm{O}_{(v)}=\mathrm{SO}_{4}^{2-}+2 \mathrm{H}^{+}+4 \mathrm{H}_{2} \\
& \log P_{\mathrm{H}_{2}}=1 / 4 \log \mathrm{K}-1 / 2 p H-1 / 4 \log _{\mathrm{SO}_{4}}^{a}+ \\
& +1 / 4 \log P_{\mathrm{H}_{2} \mathrm{~S}}+\log P_{\mathrm{H}_{2} \mathrm{O}}
\end{aligned}
$$

where $\langle g »$ and $\langle v »$ denote gas and vapour respectively.

Since from 300 to $100^{\circ} \mathrm{C}$ (the estimated deep temperature range for the submarine exhalations) the value of the $1 / 4 \log \mathrm{K}$ declines from -6.67 to -8.35 , while $\log P_{\mathrm{H}_{2} \mathrm{O}}$ declines from 1.94 to 0 , we can expect a quite large $\mathrm{H}_{2}$ partial pressure decline in the fluid up to about 4 orders of magnitude during the fluid rising. It is worth of noticing how the gas flow rate is the main parameter governing the final composi- tion of the venting gases; the proposed observations highlight the importance of the gas-water interactions occurring from the deep geothermal reservoir to the sea-bottom interface.

\subsection{Sulphur deposits}

The interaction of the gaseous $\mathrm{H}_{2} \mathrm{~S}$ with marine sulphates and with the dissolved oxygen in the seawater, can be considered the inorganic origin of the white mat, due to the following reactions (Housain and Krouse, 1978):

$$
\begin{gathered}
3 \mathrm{H}_{2} \mathrm{O}+\mathrm{SO}_{4}^{2-}+2 \mathrm{H}^{+}=4 \mathrm{H}_{2} \mathrm{O}+4 \mathrm{~S} \\
2 \mathrm{H}_{2} \mathrm{~S}+\mathrm{O}^{2}=2 \mathrm{H}_{2} \mathrm{O}+2 \mathrm{~S} .
\end{gathered}
$$

The process schematized in (3.4) gives another explanation to the $\mathrm{H}_{2} \mathrm{~S}$ oxidation to sulphur. However, even though the presence of the sulphur deposits (white mat) can be the consequence of chemical reactions at the sea-bottom interface of the hydrothermal fluids, the formation of elemental sulphur following the reaction (3.4) is considered unlike to occur due to energetic reasons. The origin of the white mat may also be microbially mediated. When brought into contact with the oxygenated waters, hydrogen sulphide becomes as energy yielding substrate for chemosynthetic colorless sulphur-oxidizing bacteria. From the oxidation of hydrogen sulphide different oxidation products may accumulate in the environment, most notably elemental sulphur in form of spherical globules or filaments of white precipitate (Taylor and Wirsen, 1997).

\subsection{Organic and inorganic mass output}

The total mass output was estimated on the basis of the measured $\mathrm{CO}_{2}$ output (which is above the $90 \%$ of the release fluids) and considering the concentration ratios of other gaseous components (table I). The $\mathrm{CO}_{2}$ output in the whole area has already been evaluated to be close to $10^{7}$ litres per day (Italiano and Nuccio, 1991). Most of the researches were concentrated on the submarine vent $\mathrm{C} 7$ : at this site a dai- 
ly release of about $2 \times 10^{5} 1$ of $\mathrm{CO}_{2}$ was measured and the output of the $\mathrm{CH}_{4}$ and $\mathrm{H}_{2} \mathrm{~S}$ gaseous components was computed as to be 0.15 and $16.5 \mathrm{~kg}$ per day respectively.

The organic carbon content in the thermal water samples at the $\mathrm{C} 7$ site, was estimated on the basis of the picoplanktonic biomass to be about $1.2 \mu \mathrm{g} / \mathrm{l}$ (table IV). As the thermal water flux at that site has been measured to be 10 $1 /$ min, a daily organic carbon flux of about 18 $\mathrm{mg}$ is calculated. Although the uncertainty of our estimations, it has to be noted that scaling this amount with the measured $\mathrm{CO}_{2}$ output, the organic carbon represents an infinitesimal percentage to the respect of the inorganic one $\left(3.9 \times 10^{5} \mathrm{~g} /\right.$ day $)$. The very high $\mathrm{CO}_{2}$ flux and the reaction kinetics seem to control the organic carbon production from the inorganic $\mathrm{CO}_{2}$ at these submarine vents. This preliminary hypothesis seems to find an agreement with the organic carbon estimations at the C5 site, which is three times higher than that of $\mathrm{C} 7$ site (about $3.9 \mu \mathrm{g} / \mathrm{l})$, while the $\mathrm{CO}_{2}$ output is only $20 \%$ respect of the $\mathrm{C} 7$ one (about $6.4 \times 10^{4} 1 /$ day).

\section{Conclusions}

The hydrothermal system of Panarea releases geothermal fluids composed of thermal waters of marine origin modified by high-temperature water-rock interactions, and $\mathrm{CO}_{2}$-dominated gases separated from a two-phase boiling system at an estimated temperature in the range of $190-314^{\circ} \mathrm{C}$.

The gases containing magmatic-type helium reveal a direct contribution of a magmatic source, either related to a cooling magma body or to a deeper connection with an active magmatic source that are both able to provide the thermal energy feeding the local geothermal reservoir.

The released geothermal energy allows the life of a variety of microorganisms that possess different nutritional requirements and overall metabolic pathways ideally suited to such ecosystem. The picoplanktonic densities estimated in samples collected were in the order of $10^{7}$ cells/l, values which were lower than those of coastal seawater samples. These values however were similar to the lower counts reported for the Galapagos Rift (Karl et al., 1980; Jannasch, 1985). The picophytoplanktonic densities were also lower than those observed in the local coastal seawater.

Chemolithotrophic, sulphur-oxidizing bacteria were isolated from thermal water samples collected at the site La Calcara. These isolates exhibited uniform morphology of short rods, with extracellular deposits of sulphur, and were tentatively identified as Thiobacillus-like bacteria. Bacterial mats appear as a white film of sulphur deposits containing numerous filaments of colorless sulphur-oxidizing bacteria of the genus Thiothrix. These formations could be a strategy for retainment in environments characterized by active fluid motion (Taylor and Wirsen, 1997). The whitish mat would also favor the growth of other microbes, since it stabilized the gradient between the sulfidic brine and the oxygenated waters.

Thermophilic, heterotrophic strains were isolated from Panarea Island and identified as Bacillus spp. Previous papers have described new species of Bacillus and Geobacillus spp. from different hot springs of the Eolian hydrothermal vents (Caccamo et al., 2000; Maugeri et al., 2001; Maugeri et al., 2002a). Some new species are able to produce novel biomolecules of biotechnological interest (Nicolaus et al., 2000; Maugeri et al., 2002b).

The close link between the geosphere (inorganic) and the biosphere (organic environment) is shown by the relationship between the deeporiginated hydrothermal fluids and the microbial communities displaying a mixed origin of the primary productivity (phototrophic and chemotrophic). This feature appears to be the main characteristic of the shallow hydrothermal vents when compared with other shallow-water regions (only phototrophic productivity) and with deep-sea hot vent areas (only chemotrophic primary productivity).

\section{REFERENCES}

Caccamo, D., C. Gugliandolo, E. Stackebrandt and T.L. MAUGeri (2000): Bacillus vulcani sp. nov., a novel thermophilic species isolated from a shallow marine hydrothermal vent, Int. J. System. Evol. Microbiol., 50, 2009-2012. 
Edmond, J.M., C.I. Measures, R.E. Mc Duff, L.H. Chan, R. Collier, B. Grant, L.I. Gordon and J.B. Corliss (1982): Ridge crest hydrothermal activity and the balance of the major and minor elements in the ocean; the Galapagos data, Earth Planet. Sci. Lett., 46, 19-30.

Fiala, G. and K.O. STETTER (1986): Pyrococcus furiosus sp. nov. represents a novel genus of marine heterotrophic archaebacteria growing optimally at $100^{\circ} \mathrm{C}$, Arch. Microbiol., 145, 56-61.

Francofonte, S., S. Inguaggiato, F. Italiano and P.M. NuCCIO (1996): Ricerca di sistemi magmatici attivi delle Isole Eolie tramite la geochimica delle esalazioni sottomarine, in Proceedings of the XII Congr. AIOL, 19-21 Settembre 1996, Vulcano, S32.

FRY, J.C. (1990): Direct methods and biomass estimation, Methods Microbiol., 22, 41-85.

Gabbianelli, G., P.V. Gillot, G. Lanzafame, M. Ligi, D. PostPISCHL and P.L. Rossi (1986): Controllo strutturale nell'evoluzione vulcanica di Panarea (Isole Eolie), IIVCNR Catania, Pubbl. 239.

Gugliandolo, C., F. Italiano, T.L. Maugeri, S. InguagGiato, D. CACCAMO and J. Amend (1999): Submarine hydrothermal vents of the Aeolian Islands: relationship between microbial communities and thermal fluids, Geomicrobiol. J., 16, 105-118.

Hafenbradl, D., M. Keller, R. Dirmeier, R. Rachel, P. Rossnagel, S. Burggraf, H. Huber and K.O. Stetter (1996): Ferroglobus placidus gen. nov., a novel hyperthermophilic archaeum that oxidizes $\mathrm{Fe}^{2+}$ at neutral $\mathrm{pH}$ under anoxic conditions, Arch. Microbiol., 166, 308314.

Housain, S.A. and H.R. Krouse (1978): Sulphur isotope effects during the reaction of sulphide with hydrogen sulphide, stable isotopes in Earth Science, DSIR Bull., 220.

Huber, R. and K.O. STETTER (1989): Thiobacillus prosperus $\mathrm{sp}$. nov. represents a new group of halotolerant metal-mobilizing bacteria isolated from a marine geothermal field, Arch. Microbiol., 151, 479-485.

Huber, R., T.A. LAngworthy, H. König, M. Thomm, C.R. Woese, U.B. Sleytr and K.O. Stetter (1986): Thermotoga maritima sp. nov. represents a new genus of unique extremely thermophilic eubacteria growing up to $90^{\circ} \mathrm{C}$, Arch. Microbiol., 144, 324-333.

Inguaggiato, S. and F. Italiano (1998): Helium and carbon isotopes in submarine gases from the Aeolian arc (Southern Italy), in Proceeding of the 9th Iinternational Symposium on Water-Rock Interaction-WRI9, 30 March-3 April 1998, Taupo, New Zealand (Arehart \& Hulston, Rotterdam), 727-730

ItALIANO, F. and P.M. NuCCIO (1991): Geochemical investigations of submarine volcanic exhalations to the east of Panarea, Aeolian Islands, Italy, J. Volcanol. Geotherm. Res., 46, 125-141.

JacQ, E., D. Prieur, P. Nichols, D.C. White, T. Porter and G.G. GEESEY (1989): Microscopic exhaminations of fatty acid characterization of filamentous bacteria colonizing substrata around subtidal hydrothermal vents, Arch. Microbiol., 152, 64-71.

JANNASCH, H.W. (1985): Chemosynthetic support of life and the microbial diversity at the deep-sea hydrothermal vents, Proc. R. Soc. London, 225, 277-297.

JANNASCH, H.W. and C.O WIRSEN (1981): Morphological survey of microbial mats near deep-sea thermal vents, Appl. Environ. Microbiol., 41, 528-538.

Karl, D.M., C.O. WIRSEN and H.W. Jannasch (1980): Deep-sea primary production at the Galapagos hydrothermal vents, Science, 207, 1345-1347.

Kelly, D.P. and A.P. Harrison (1989): Genus Thiobacillus, in Bergey's Manual of Systematic Bacteriology, edited by J.T. Stanley, M.P. BRyant, N. PFEnNig and J.G. HoLT (Williams and Wilkins Press, Baltimora), vol. 3 , 1842-1858.

LeE, S. and A. Fuhrman (1987): Relationships between biovolume and biomass of naturally derived marine bacterioplankton, Appl. Environ. Microbiol., 53, 12981303.

Maugeri, T.L., M.L.C. Acosta Pomar and V. Bruni (1990): Picoplancton, in Metodi per lo Studio del Plancton Marino, edited by M. INNAMORATI, I. FERRARI, M. DONATO and M. Ribera D’Alcalà, Nova Thalassia (Trieste), vol. 11, 199-205.

Maugeri, T.L., C. Gugliandolo, D. Caccamo and E. STACKEBRANDT (2001): A polyphasic taxonomic study of thermophilic bacilli from shallow, marine vents, System. Appl. Microbiol., 24, 451-468.

Maugeri, T.L., C. Gugliandolo, D. Caccamo and E. STACKEBRANDT (2002a): Three novel halotolerant and thermophilic Geobacillus strains from shallow marine vents, System. Appl. Microbiol., 24, 450-455.

Maugeri, T.L., C. Gugliandolo, D. Caccamo, A. Panico, L. LAma, A. Gambacorta and B. Nicolaus (2002b): A halophilic thermotolerant Bacillus isolated from a marine hot spring able to produce a new exopolysaccharide, Biotechnol. Lett., 24, 515-519.

Nicolaus, B., A. Panico, M.C. Manca, L. Lama, A. GamBacorta, T.L. Maugeri, C. Gugliandolo and D. CACCAMO (2000): A thermophilic Bacillus isolated from an Eolian shallow hydrothermal vent, able to produce exopolysaccharides, System. Appl. Microbiol., 23, 426432.

Porter, K.G. and Y.S. FeIG (1980): The use of DAPI for identifying and counting of aquatic microflora, Limnol. Oceanogr., 25, 943-948.

Rossi, P.L., G. Bocchi, N. Calanchi, G. Lanzafame, F. LUCCHINi and R. ROMANO (1986): Evoluzione vulcanotettonica e geochimica dell'apparato di Panarea (Isole Eolie), Rend. Soc. Ital. Min. Petr., 41 (1), 144-145.

Ruby, E.G., C.O. Wirsen and H.W. JANNASCH (1981): Chemolithotrophic sulphur oxidizing bacteria from Galapagos Rift hydrothermal vents, Appl. Environ. Microbiol., 42, 317-324.

Sieburth, J.M., V. SMetaceK and J. LenZ (1978): Pelagic ecosystem structure: heterotrophic compartments of the plankton and their relationship to plankton size fractions, Limnol. Oceanogr., 34, 1256-1263.

Stetter, K.O., H. Konig and E. Stackebrandt (1983): $P y$ rodictium gen. nov., a new genus of submarine discshaped sulphur-reducing Archaebacteria growing optimally at $105^{\circ} \mathrm{C}$, System. Appl. Microbiol., 4, 535-551.

TAYLOR, C.D. and C.O. WIRSEN (1997): Microbiology and ecology of filamentous sulfur formation, Science, $\mathbf{2 7 7}$, 1483-1485.

TutTLE, J.H. and H.W. JANNASCH (1972): Occurrence and types of Thiobacillus-like bacteria in the sea, Limnol. Oceanogr., 32, 591-607. 
TutTle, J.H., C.O. WIRSEN and H.W. JANNASCH (1983): Microbial activities in the emitted hydrothermal waters of the Galapagos Rift vents, Mar. Biol., 73, 293-299.

von DAMM, K.L., J.M. EDMOND, B. GRANT, C.I. MEASURES,

B. WALDEN and R.F. WeISS (1985): Chemistry of sub- marine hydrothermal solutions at $21^{\circ} \mathrm{N}$, East Pacific Rise, Geochim. Cosmochim. Acta, 49, 2197-2220.

Wirsen, C.O., J.H. TutTlE and H.W. JANnAsCH (1986): Activities of sulfur-oxidizing bacteria at the $21^{\circ} \mathrm{N}$ East Pacific Rise vent site, Mar Biol., 92, 449-456. 